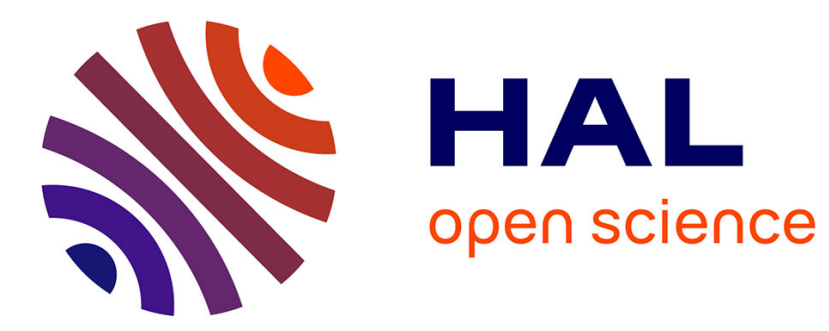

\title{
Talpa aquitania sp. nov. (Talpidae, Soricomorpha), a new mole species from SW France and N Spain
}

Violaine Nicolas, Jessica Martínez-Vargas, Jean-Pierre Hugot

\section{To cite this version:}

Violaine Nicolas, Jessica Martínez-Vargas, Jean-Pierre Hugot. Talpa aquitania sp. nov. (Talpidae, Soricomorpha), a new mole species from SW France and N Spain. Mammalia, 2017, 81 (6), pp.641-642. 10.1515/mammalia-2017-0057 . hal-01829495

\section{HAL Id: hal-01829495 \\ https://hal.sorbonne-universite.fr/hal-01829495}

Submitted on 4 Jul 2018

HAL is a multi-disciplinary open access archive for the deposit and dissemination of scientific research documents, whether they are published or not. The documents may come from teaching and research institutions in France or abroad, or from public or private research centers.
L'archive ouverte pluridisciplinaire HAL, est destinée au dépôt et à la diffusion de documents scientifiques de niveau recherche, publiés ou non, émanant des établissements d'enseignement et de recherche français ou étrangers, des laboratoires publics ou privés. 
Violaine Nicolas, Jessica Martínez-Vargas and Jean-Pierre Hugot*

\section{Talpa aquitania sp. nov. (Talpidae, Soricomorpha), a new mole species from SW France and N Spain}

\section{Talpa aquitania}

\section{Introduction}

We recently published the diagnosis and the name of a new mammal species: Talpa aquitania Nicolas, MartínezVargas et Hugot 2015. Unfortunately, it happened that the editors of the Bulletin de l'Académie Vétérinaire de France, the selected journal, decided to stop the paper edition for their publication. An attentive examination of the corresponding articles of the International Code on Zoological Nomenclature (Art. 8) shows that, to be valid, a new name must be published on a paper support or electronically after being pre-registered in the Official Register of Zoological Nomenclature (ZooBank) before publication. Thus, in this situation we have a risk that our work will not be considered published, and therefore our new taxon considered not available. This is the reason why we publish the present article in a periodical printed on paper, distributed simultaneously to all subscribers and accessible online after its paper distribution, which makes our new name available under the traditional rules of zoological nomenclature. In the following we are giving the essentials of the diagnosis of the new taxon. For the details of the molecular phylogenetic, morphological and biogeographical information, we refer to our previous original works (Nicolas et al. 2015, 2017).

\footnotetext{
*Corresponding author: Jean-Pierre Hugot, Institut de Systématique, Evolution, Biodiversité, ISYEB UMR 7205 - CNRS, MNHN, UPMC, EPHE, Muséum National d'Histoire Naturelle, Sorbonne Universités, Paris, France, e-mail: hugot@mnhn.fr Violaine Nicolas: Institut de Systématique, Evolution, Biodiversité, ISYEB UMR 7205 - CNRS, MNHN, UPMC, EPHE, Muséum National d'Histoire Naturelle, Sorbonne Universités, Paris, France Jessica Martínez-Vargas: Departament de Biologia Animal, de Biologia Vegetal i d'Ecologia, Facultat de Biociències, Universitat Autònoma de Barcelona, E-08193 Bellaterra (Cerdanyola del Vallès), Barcelona, Spain
}

\section{Holotype}

MNHN-ZM-2016-471 (VN1789). Collected in 2013. France86280, Saint-Benoît, $46.546^{\circ} \mathrm{N}-0.348^{\circ} \mathrm{W}$. Adult female: whole body preserved in ethanol.

\section{Paratypes}

Tissues preserved in ethanol and RnaLater; skulls extracted (national collection number, field number, date of collect, locality and district of collection, geographic coordinates, name of collector, age and sex). MNHN-ZM2016-472 (YA0346). 06/10/2013, France-63320, Creste, Issoire, $45.550^{\circ} \mathrm{N}-3.043^{\circ} \mathrm{W}$, Bernard Pradier, adult female. MNHN-ZM-2016-473 (YA0386). 13/04/2014, France-63190, Lezoux, alt. $833 \mathrm{~m}, 45.828^{\circ} \mathrm{N}-3.380^{\circ} \mathrm{W}$, J-Michel Georgeon, adult female.

\section{Diagnosis and distribution}

Talpa aquitania can unambiguously be distinguished from its sister-related species, Talpa europaea Linnaeus 1758 and Talpa occidentalis Cabrera 1907, by a unique combination of characters:

The eyelids are fused together. As observed in Talpa occidentalis, the eye is completely covered by membranes. This characteristic differs from what is observed in Talpa europaea, which has open eyes.

Weight, head, body and hind-foot lengths are significantly greater in Talpa aquitania (weight: $89 \pm 17 \mathrm{~g}$, head and body: $149 \pm 7 \mathrm{~mm}$, foot: $21.5 \pm 1.5 \mathrm{~mm}$ ) than in Talpa europaea and Talpa occidentalis (Nicolas et al. 2015).

The mesostyle of the upper first molar (M1) is simple in Talpa aquitania and Talpa europaea, while it is double in Talpa occidentalis. In T. occidentalis and T. europaea, the mesostyles of the upper second molar (M2) and the upper third molar (M3) are divided into two cusps. The 
two cusps are of subequal size, and they are aligned on a plane that extends parallel to the parastyle and the metastyle. Some T. aquitania specimens have a simple mesostyle in M2, and other specimens show an additional minute cusp. Unlike in T. europaea and T. occidentalis, this cusp is much smaller than the main cusp of the mesostyle and is located in the crest that connects the mesostyle to the metacone of M2 that is in a more lingual position than the mesostyle itself. In the M3 of some T. aquitania specimens, the mesostyle is composed of a main anterior cusp and a slightly smaller posterior cusp (see figure 4 in Nicolas et al. 2015, figure 6 in Nicolas et al. 2017). In other specimens, this posterior cusp is not clearly discernible because its posterior border is fused to the crest that runs from the mesostyle to the metacone of M3. Despite interindividual variability, the mesostyle condition of M2 and M3 of T. aquitania specimens differs from that found in $T$. europaea and T. occidentalis.

Base composition of 16 positions of the cytochrome b gene differ between Talpa aquitania and the two other species (based on 216 specimens of Talpa europaea, 118 specimens of T. aquitania and 26 specimens of Talpa occidentalis; Nicolas et al. 2017). Base composition at positions $87,171,176,282,309,328,351,369,465$, 492, 745,
813, 828, 981, 1047 and 1074 is C, G, C, G, T, T, A, A, T, C, T, G, C, A, T, T in T. aquitania, and it is A, A, T, A, C, A, G, G, C, T, C, A, T, T, C, C in both T. europaea and T. occidentalis.

Talpa aquitania is present in France southward and westward of the Loire River, and in Northern Spain.

Acknowledgments: We are grateful to Philippe Bouchet and Alain Dubois who drew our attention to this issue related to the code of nomenclature.

\section{References}

Anonymous [International Commission on Zoological Nomenclature]. 2012. Amendment of Articles 8, 9, 10, 21 and 78 of the International Code of Zoological nomenclature to expand and refine methods of publication. Bull. Zool. Nom. 69: 161-169.

Nicolas, V., J. Martínez-Vargas, J.-P. Hugot. 2015. Talpa aquitania nov. sp. (Talpidae, Soricomorpha) a new mole species from southwest France and north Spain. Bull. Acad. Vet. Fr. 168: 329-334.

Nicolas, V., J. Martínez-Vargas, J.-P. Hugot. 2017. Molecular data and ecological niche modelling reveal the evolutionary history of the common and Iberian moles (Talpidae) in Europe. Zool. Scripta 46: 12-26. 